\title{
1. Introduction: children in the context of changing families and welfare states $^{1}$
}

\section{Jane Lewis}

The nature of the relationship between children, parents and the state has been central to the growth of the modern welfare state and has long been a problem for western liberal democracies. Historically, children have been conceptualised as belonging to the private world of the family and thus to their parents, and policymakers have been preoccupied with the question: in what circumstances can, or should, the state intervene to protect children or to ensure that opportunities exist for their development? Many governments have been concerned that state intervention on behalf of children will serve to relieve parents of their responsibilities, and it has often proved difficult to establish a relationship that is not adversarial. As Hendrick (1990) has pointed out, such issues have played an important part in defining the very meaning of modern childhood. More recently, there has been increased emphasis on the idea that collective investment in children is crucial to the welfare of society, leaving open the extent to which the welfare of the child qua child is a central consideration. This has raised additional questions about how far children's views are taken into account at a time when academic commentators have been stressing the importance of listening to the voice of the child.

At the level of the individual household, the family has tended to be left alone except when a child has been abused or neglected, or when the child has been considered to constitute a (criminal) threat. In these instances the state has taken action to remove the child. But commentators have mounted a strong defence of 'family privacy' in liberal democracies (for example, Elshtain 1990; Mount 1983), although as Gordon (1988) showed in her historical study of social work/domestic violence in Boston, state intervention by embryonic social workers at the household level was often taken on behalf of the powerless - women and children - in the context of an essentially patriarchal family form. 
But the nature of the relationship between child, parent and state has developed very differently in different nation states. English-speaking countries have had much more suspicion of state intervention in the family, and have tended historically to limit direct intervention not only at the household level but also in respect of the collective support of children via cash benefits and services, particularly childcare services. Only the USA failed to develop any system of universal 'family allowances' or child benefits, which provide (varying amounts) of recognition as to the cost of raising a child, but the care of children has been much more likely to be treated as a 'family' (usually women's) responsibility in large tracts of Europe as well as North America. In the UK, for example, the problem of childcare was not considered to be an issue for state policy until the late 1990s; men and women were free to enter the labour market, but were expected to make their own arrangements regarding care for their children. This sort of approach has contrasted markedly with that in other Northern and Western European countries, where it has been considered first, a duty on the part of the state to support children financially and in respect of their care; and second, where this duty is seen as one to be undertaken in partnership with parents, particularly in the Scandinavian countries.

Nevertheless children have come to the fore on policy agendas in recent years in most western states, with both the policy drivers and the policy responses taking many forms. In respect of the former, first there is what has been termed by most recent writers on welfare state change 'the demographic challenge' (for example, Pierson 2001). All western countries are ageing, birth rates are falling and the worsening dependency ratios mean that pensions and health and social care for older people are becoming harder to afford. Thus a major reason for putting children on the policy agenda is their absence. Most recently policies addressing childcare and support have been framed in terms of what might 'enable' parents to have the number of children they desire (for example CEC 2005). ${ }^{2}$ Second, there has been a greater interest in the relationship between family change and welfare state change. Indeed, many analysts have begun to realise the extent to which household change in respect of both family form and the contributions that adult men and women make to families is driving policy (for example Esping-Andersen 1999), as well as being shaped by it. The first substantive section of this introduction explores these relationships as a means of providing the background for what is a fundamental shift in thinking about the orientation of welfare states that also has major implications for children.

Broadly speaking, states have pursued what has been termed a more 'active' approach to social entitlements for adults by drawing a tighter link between employment and social provision, and a stricter social investment approach to welfare spending in general. In this context, considerable 
attention has focused on children as future citizen workers, but responses have been varied and not necessarily of a piece. The tensions can be particularly stark in some countries at the household level. For example in the UK, as many commentators have pointed out, there have been moral panics about both the threat posed by a-social and criminal behaviour on the part of children, which has resulted in the effective lowering of the age of criminal responsibility to ten (the lowest in the EU), at the same time as there has been massive outcry about the failure to protect children abused by kin and carers (see James and James 2001 for a particularly critical review of UK government policy).

But the focus of this book is more on the implications of social policies to do with the arrangements for the care and support of children than on the nature of intervention at the level of the household, ${ }^{3}$ and here too it is possible to identify very different approaches. One major strand in the early English-speaking commentary on changes in family form, and the increasingly high rates of lone parenthood resulting from high and stable divorce rates and high rates of cohabitation, has been the perceived collapse of family values and the lack of proper socialisation of children, ${ }^{4}$ with the solution being sought in the traditional, married, two-parent family, and a rolling back of state support. This is a response that stands to have a detrimental impact on the welfare of children in poor families, certainly in the present generation, and that has proved more influential in the USA than in Europe, other than in the UK during the 1980s and early 1990s (Kiernan et al. 1998; Lewis 1997).

However, since the late 1990s, the demographic challenge has resulted in something of a premium being attached to children in EU member states, all of which have experienced a decline in their birth rates (the decline has been precipitous in Southern Europe; Douglass 2005). One of the most striking recent developments in European countries has been the emphasis on 'investing' in children as part of a social investment state (explored further in Part I of this book). A focus on children's welfare because of their future role as adult citizens is hardly new in and of itself: the whole apparatus of state education was designed to do just that in the service of both the child, and also, crucially, of economic growth and social harmony. However, the reorientation of the modern welfare state toward expenditure that can be represented in terms of investment, whether in the form of active labour market policies (rather than 'passive' welfare benefits for the unemployed), or family policies to support children as future investments is new. This stronger focus on children looks as though it should bring unadulterated benefits. But one of the major issues that arises from this new orientation is how far the policy responses are actually child-centred. 
A major issue in the literature on the sociology of childhood is the extent to which children are viewed as agents, rather than acted on. This literature, which is explored in the second substantive section of this introduction, has particular policy relevance in regard to measures that impact directly on households - for example, in respect of post-divorce parenting - but is important for our purposes in this book for the way in which it alerts us to how far policy responses are actually driven by concerns about the welfare of children per se. We explore two areas of policy of fundamental importance to children: their financial support and care. One of the issues we explore is how far such policies may be described as 'instrumental', in other words, how far they are about issues other than the welfare of the child, such as encouraging fertility and women's employment, both of which are argued to be necessary to address the problem of the deteriorating dependency ratio, or encouraging economic growth, by investing in children's early learning. Such a policy may bring very real benefits for children but, as this introduction argues, it is nevertheless important to consider what more genuinely child-centred policymaking might look like, and to take into account children's own perspectives.

\section{CONTEXT: FAMILY AND WELFARE STATE CHANGE}

It is now widely recognised that family change, involving both demographic change and the changing nature of the contributions that adults make to families via paid and unpaid work, is of major importance to our understanding of the complex relationship between families, markets and states. Dramatic and interlinked changes in families and households, in labour markets, and in systems of social provision and regulation have been underway for some time now. Families and labour markets are moving towards increasing 'individualisation', with the erosion of traditional family bonds (manifested in low fertility, higher rates of divorce, extra-marital births, lone parenthood and increasing numbers of single-person households) and, with steadily rising rates of female participation in the workforce, more economic independence among women.

Traditional patterns of social provision in welfare states assumed the existence of a particular kind of family form, comprising a stable, twoparent, primary male earner and primary female carer model, and sought to provide protection against specified eventualities or risks - such as ill health and unemployment - within the confines of that family model. Core forms of social provision, for example in the form of social insurance benefits (and core approaches to family law, for example in respect of establishing fault and hence entitlement to alimony on divorce) rested on these 
basic assumptions as to what the family looked like and how it worked. It has recently been suggested that the erosion of the traditional family model has brought with it 'new social risks' (Bonoli 2005), which by definition cannot be addressed within the old frameworks. Thus, for example, the recent effort at EU level and by policymakers in most member states to further increase the level of female employment has also brought with it more attention to the provision of childcare, even in countries where this has been historically a low policy priority. This section attempts to summarise family and welfare state change, both of which have major implications for the support and care of children.

\section{The Nature of Family Change}

The settlement at the heart of modern welfare states was that between capital and labour. But it is increasingly recognised that there was a second key settlement between men and women at the household level. Partly as a result of feminist critique (for example, Lewis 1992; Orloff 1993), and partly because the nature and pace of change have made it much harder to ignore, recent comparative work on social provision has paid far greater attention to family arrangements and to gender relations (Crouch 1999; EspingAndersen 1999; Huber and Stephens 2001; Korpi 2000). The old labour contract was designed first and foremost for the regularly employed male breadwinner and provision had to be made alongside it for women and children. The gendered nature of the settlement meant that those marginal to the labour market received cash cover via dependants' benefits paid to the male breadwinner. The male breadwinner family model was based on a set of assumptions about male and female contributions at the household level, with men being expected to take primary responsibility for earning, and women for household work and caring for the young and the old. Female dependence was inscribed in the model, and with it the dependence of children. In the inter-war period, the British feminist and campaigner for family allowances, Eleanor Rathbone (1924), raised the question that has remained crucial ever since: what is the wage for? Designed as a reward for individual effort in the labour market, it has always been difficult to see how a male wage can provide effectively for wives and differing numbers of children. In recognition of this, dependants' allowances were written into different kinds of cash benefits, and some effort was made in all western countries except the USA to provide a benefit in the form of a 'family allowance' in respect of all children, usually paid to the mother. However, this has remained a relatively small, albeit important, part of social security systems.

Crucially, the male breadwinner model built into the post-war settlement assumed regular and full male employment and stable families, in which 
women and children would be provided for largely via their husbands' earnings and their husbands' social contributions. High rates of family instability; much greater fluidity in intimate relationships (such that cohabitation may precede marriage and post-date divorce, and high rates of extra-marital childbearing in many western countries); together with rising rates of female labour market participation, especially among mothers of young children, made it impossible to sustain the traditional gender settlement that underpinned social provision and regulation in modern welfare states. Above all, the rising proportion of lone mother families have made considerable claims on social provision.

Thus the male breadwinner model family has substantially eroded in two key respects: the changing pattern of women's and to a much lesser extent men's contributions to the family in respect of cash (more than care), and the changing structure of the family itself. It seems that on both the work and the family front we are seeing more individualisation. Elizabeth BeckGernsheim (1999, p. 54) has described the effects of individualisation on the family in terms of 'a community of need' becoming 'an elective relationship'. Elias (1991, p. 204) expressed a similar idea in the following: 'The greater impermanence of we-relationships, which at earlier stages often had the lifelong inescapable character of an external constraint, puts all the more emphasis on the I, one's own person, as the only permanent factor, the only person with whom one must live one's whole life.' In this interpretation, the family used to be a community of need held together by the obligations of solidarity. But women's increased labour market participation, together with family instability and fluidity, has resulted in new divisions between biography and family.

Changes in family form and in patterns of both income and working time impact directly on the welfare of children, especially when policymakers begin to assume that adults can increasingly be treated as fully individualised, in the sense of being economically independent. In increasingly fluid families, children still tend to end up living with biological mothers (and often subsequently in families with men who are not their biological fathers), so arrangements that are made to support women as mothers become particularly important. Divorce is high and stable in northern Europe, with more moderate rates in continental Western Europe and low rates in the South, albeit with rising rates of separation. There have been extraordinary rises in the proportion of live births outside marriage in northern Europe, wide variations in the increase in the continental Western European countries (high in France, low in the former West Germany), and wide variations in Southern European countries (Portugal had a higher rate than many northern countries as early as 1960 and a higher rate than Germany in 1995; Lewis 2003a). Divorce and unmarried motherhood are 
routes to lone motherhood, with cohabitation driving much of the change, and the proportions of lone mother families have therefore increased. It remains the case that children's material welfare depends disproportionately on the welfare of women. Thus children have been adversely affected by the well-documented increase in the feminisation of poverty (for example, Sharma 2005).

Changes in the nature of the contributions men and women make to families also vary between countries, with particular implications for children. Nowhere is there a fully fledged adult worker model family. Indeed, while in Western Europe there is evidence of substantial movement away from the male breadwinner model towards a citizen worker model (Crompton 1999; Lewis 2001), it is most common to find some form of transitional dual breadwinner model than a full dual career model. Indeed, dual-earner families have become the norm in most western countries, although the number of hours women work outside the home varies hugely (Rubery et al. 1999). Labour participation rates are low in Southern Europe, but women tend to work full time, while in much of Western Europe more women work, but part time, in a one-and-a-half earner model, extending to a one-and-three-quarter model in the Scandinavian countries. In most Western European countries part-time work for women has been the main way of reconciling work and family responsibilities and hence providing for the care of children, especially in countries like the UK, the Netherlands and Germany where a large proportion of women work short part-time hours (under 15 hours a week). The vast majority of men have continued to work full time and in the English-speaking countries a significant proportion (just over 31 per cent of UK fathers with children under 16) work more than the 48 hours laid down by the European Commission's 1996 Working Time Directive (Gershuny 2000; Smith 2004).

It is often assumed that the increased employment of women has a beneficial effect on child poverty rates. This may be so, but in countries where formal childcare costs are high and the gender pay gap is wide, for example in the UK (see Manning and Petrongolo 2005), it is less likely to be the case. Changing patterns of time-use on the part of adults also affect children, indeed, Mutari and Figart (2001) have argued that gender differentiation in families is increasingly based on time. These different patterns of male and female employment at the household level are accompanied by very different ways of making provision for the care of children. But as the hours women work lengthen, so mothers and fathers in twoparent families must either engage in 'shift parenting' (very common in the UK and the USA), or seek help from kin, or a daycare place. Countries differ enormously in how much state help has been offered to parents by 
providing either childcare services, or cash benefits that enable parents (usually mothers) to stay at home or to buy childcare.

Adults increasingly undertake a series of transitions over the lifecourse, in and out of intimate relationships and in and out of paid and unpaid work. These must be negotiated. Considerable caution is nevertheless needed when assessing the extent of change. After all, a majority of children are still brought up in two-parent families in which women are far from economically independent. However, first, it is striking how processes of individualisation are often discussed without mention of the implications for children. Second, and more problematic from the point of view of everyday living, when policymakers begin to assume greater economic independence on the part of adults, this may have particularly grave consequences for children, who often end up living with their relatively poorer mothers. As those mothers are encouraged to increase their hours of paid work, children may also experience childcare that is not necessarily high quality.

\section{'New Social Risks' and the Changing Assumptions Underpinning Policy}

The structure of modern welfare systems has never provided well for those who were marginal in some way to the labour market. Thus we might expect part-time women workers and lone mothers to have been relatively poorly provided for. In the case of the latter - by definition women with children and without men - only widows have been able to rely on derived benefits, consisting of social insurance benefits paid for by their husbands' contributions. These are invariably higher than the means-tested social assistance benefits that the growing proportion of divorced and unmarried mothers end up depending on, supplemented by whatever money the state is able to extract from the 'absent' father. In most western countries these women and their children have remained disproportionately poor. In other words, changes in the labour market, particularly in respect of women's precarious place in it, and in family form have thrown up new groups facing the old risk of poverty.

The links between men, the labour market and the traditional family have been eroded by more fluid families, more female employment and more flexible employment. At the same time, the linkage between labour markets and welfare, broadly defined, has intensified over the past two decades, with new forms of conditionality being imposed via welfareto-work schemes. Thus, alongside labour market and family change, welfare state restructuring has made the welfare of all adults, male and female, increasingly dependent on their success in the labour market at a time of increasing flexibilisation. As Yeandle (1999, p. 142) has observed, a complex relationship between individuals and labour markets is emerging 
across the life course, which is 'fraught with risk' and 'requires skilful negotiation'. In addition, recent research has revealed the extent to which children are also involved in negotiations arising from family change, whether at the household level, for example, following family breakdown (Smart et al. 2001), or attendant on the changing pattern of women's employment and its effects on children's household work and the organisation of their time (for example Brannen et al. 2000).

Individualisation in the sense of increasing economic independence and more autonomy to choose and to move between different kinds of intimate relationships has increasingly been matched by new assumptions on the part of policymakers regarding the part men and women play in families. What is crucial from the perspective of children are the terms and conditions on which this shift in assumptions has been pursued. In practice, the nature of the policy logics that underpin different adult worker models in different countries varies enormously. Only in the USA and in some of the Nordic countries have policies been based on the assumption that men and women will be fully engaged in the labour market. However, these models work in very different ways. In the US case, the obligation to enter the labour market is embedded in a residual welfare system that often borders on the punitive, whereas in Scandinavia it is supported by an extensive range of care entitlements in respect of children in particular. In addition, only in the Nordic countries has policy attempted to address the way in which unpaid work is shared at the household level, by making it possible for men to take paid 'daddy leave'. In the USA, an adult worker model family has been promoted with no support for care work in the family. Perhaps not surprisingly, studies of the 'time squeeze' and of family stress have most commonly emanated from the USA (Schor 2001; Skocpol 2000; Heymann 2000).

There also remains a substantial strand of opinion that promotes more traditional family roles and relationships, particularly in the Englishspeaking countries, but also in many continental European countries. In Germany, for example, the Federal Government and Länder have long promoted the 'choice' for mothers of young children to stay at home or enter employment, and mothers continue to express a preference for part-time work (European Foundation 2000); and the tax system is still not individualised (Dingeldey 2001). Nevertheless, there is considerable convergence between different countries in terms of governments' efforts to promote an 'adult worker model family' in the hope of doing many things: promote economic growth, tackle poverty, further gender equality (in the labour market), and combat the problem of deteriorating dependency ratios. All of these rationales have been mentioned by different groups and political parties in different countries at different moments. They are not equally 
important policy drivers, and some, particularly gender equality, are largely rhetorical (Stratigaki 2004, 2005), but increasingly, as policy assumptions change, all adults will be at risk (particularly in respect of pension provision), if they are not in the labour market. Indeed the shift to an adult worker model family can be read as evidence of the privatisation of risk to the individual and/or the family (Brush 2002).

The policy drivers behind the new assumptions of an adult worker citizen signal the extent to which the shift in the policy assumptions has been instrumental: the welfare of women, whose behaviour is expected to change most, is not necessarily at the centre of policymaking (Lewis 2002). Nor are the policy implications in respect of children's welfare a central matter for consideration. 'Active' welfare provision, entailing tighter conditionality between social provision and the labour market has been extended to adult women as well as tightened for adult men, raising the question of how we make provision for the care of children. The new assumptions regarding the desirability of an adult worker model family are framed within the need to take a 'social investment' approach to welfare expenditure, justifying it on the basis of future returns, whether in relation to cash benefits designed to promote economic activity on the part of adults and hence economic growth, or expenditure on early years learning, designed in the main to produce more employable workers in the future. This new orientation to welfare has meant that more attention has been directed towards children, albeit more on the basis of their 'becoming' rather than their 'being'. Nevertheless, there have also been substantial benefits for children in the here and now, particularly in terms of the way in which child poverty has moved rapidly up the policy agenda.

The policy trends may be illustrated briefly by reference to developments at the EU level. Employment growth has been seen as a key social policy goal and as a means of promoting social inclusion, a position shared by European social democrats (for example Vandenbroucke 2001). However, the emphasis in respect of the promotion of women's employment, especially of lone mothers, has been somewhat different, having much to do with tackling poverty and limiting expenditure on welfare benefits (Rowlingson and Millar 2001). But, this may ignore the perceptions on the part of lone mothers that the risk their absence from home poses to their children may be greater than the absence of income, and their desire to put childrearing first (Duncan and Edwards 1999).

Over the last decade the European Commission has increasingly stressed the importance of the effective use of women's skills in a competitive, knowledge-based economy (CEC 2000), and has received academic backing for its position. Women have been seen as an untapped labour reserve. Reports to the Portuguese Presidency in 2000 (Ferrera et al. 2000) 
and to the Belgian Presidency in 2001 (by Esping-Andersen, 2001) favoured higher female labour market participation for instrumental reasons, as a means of increasing both competitiveness and the tax base of the continental European social insurance welfare states. The Lisbon Council set a target of 60 per cent for female labour market participation in member states by 2010 (Council of the European Union 2000), and the following year the Stockholm European Council set an interim target of 57 per cent by 2005 (Council of the European Union 2001). The Commission has called in addition for 'reforms of means-tested benefits so that each member of the household has an incentive to work' (CEC 2002). However, in most countries there has been insufficient attention to the terms and conditions under which the transition to an adult worker model family is undertaken, and in particular to the linked problems of how carework for children (and older people) is to be accomplished.

Increasing women's paid work is part of, but not the whole, solution to the problem of poverty, particularly child poverty, not least because of the gender pay gap, which has proved difficult to shrink (Rubery 2002), and because women continue to do a disproportionate amount of unpaid carework. The trend in welfare state restructuring towards an adult worker model family increasingly assumes that more care will become commodified and that women will become paid rather than unpaid carers (for example Esping-Andersen et al. 2002). Policymakers have increasingly promoted non-familial childcare in conjunction with the shift to an adult worker model family, as well as in order to promote 'early learning' and thus better opportunities in the labour market in the future (for the UK, see Lewis 2003b). In 2002 a benchmark for childcare was set by the Barcelona Council in 2003, whereby at least 33 per cent of children under three years of age and at least 90 per cent of children between three and the mandatory school age should have access to childcare by 2010 , but again the rationale was phrased more in terms of the welfare of the child and of society in the future rather than in the present. There is in fact an increasingly complicated and mutually reinforcing set of drivers behind the promotion of formal childcare at EU and member state level. For example, in Germany during the $1990 \mathrm{~s}$, the desirability of childcare outside the family became increasingly accepted, fuelled by falling fertility rates (to 1.29 in 2001), Germany's poor showing in the OECD's PISA report on performance in schools (OECD 2001), and increased female labour market participation rates (Evers et al. 2006). ${ }^{5}$

Thus women's work has been broadly encouraged, and for a wide variety of reasons. The care of, and support for, children has also become more of a policy priority, in large part because of the changing contribution to family life made by their mothers, and also because of the increased 
attention given to the importance of investing in the next generation. Indeed, the benefits for the economy and society have tended to take precedence over those for individual women and children. In particular, increased female labour force participation has created a new imperative for childcare provision. Institutional provision has found new support in the research evidence, which has increasingly swung away from condemning the effects of maternal employment on young children and towards endorsing formal daycare, at least for children over three (Gregg and Washbrook 2003), with the proviso that it is high quality care. However, outside the Scandinavian countries - where daycare was developed much earlier and where arguments about the welfare of the child were much more central (see Borchorst 2000 on Denmark; see also Dahlberg et al. 1999) - the approach has also tended to be rather instrumental, with the desire to promote female employment, and, most recently, concerns to help women reconcile work and family as a means of increasing birth rates (CEC 2005) taking precedence over the needs of children.

\section{CHILDREN AND THE NEED FOR A MORE CHILD- CENTRED APPROACH TO POLICYMAKING}

Children have become increasingly 'precious' at both household and societal levels. Zelizer (1985) argued that as children lost their economic value to their parents and became a drain on their material resources, they also became emotionally 'priceless'. Beck and Beck-Gernsheim (1995; see also Beck-Gernsheim 2002) have argued that as adult relationships have become more individualised, so the emotional link with children has become more attractive. At the societal level, both the 'scarcity' of children due to the fall in the birth rate, and increased recognition of the need for a highly educated workforce in the 'knowledge economy' have moved children up the policy agenda, but in relation more to children's future role as citizen workers than to the welfare of the child qua child.

Despite the focus on children by the end of the twentieth century, evidence regarding their welfare was far from encouraging, particularly in terms of child poverty rates (Bradshaw 2000; Vleminckx and Smeeding 2001; Ritakallio and Bradshaw 2006). At the turn of the new century, the USA, the UK, Canada and Italy had child poverty rates well above their overall poverty rates, although between 1996 and 2001 child poverty fell in most EU countries, including the UK, Germany and the Netherlands. Considerable (and often polemical) fears have also been expressed over the effects on children of family breakdown and the freedom of adults to move from relationship to relationship. ${ }^{6}$ Gillis (2003) has suggested that we are 
increasingly living through children, rather than reciprocally with them. While early twenty-first century children may have more symbolic power, they have lost actual power (Jensen 2003).

There has been relatively little analysis of the position of children in the context of changing families and welfare states. As adults become increasingly individualised in the sense of being economically independent, children remain economically dependent for longer on their families. And as adult women play a greater role in the public sphere, children are increasingly confined to the private world of the family, because of anxieties about their safety and because of the changes in leisure patterns wrought by new technology and media (Livingstone 2002).

Nor do children have much power of voice or exit over the changing ways in which family life is organised, particularly in respect of the politics of time, which has special significance for the lives of children (Jensen and McKee 2003). The idea of the 'hurried child' has been used to suggest both that childhood is more fleeting (Lynott and Logue 1993) and that in the new adult worker model family, children and adults may be on different time schedules (Gillis 2003). In the last chapter of her pathbreaking book, Zelizer (1985) suggested that the role of children may change in the future because of women's increasing labour market participation, in other words, children may again be expected to do more by way of domestic labour (see also Miller 2005). As Brannen et al. (2000) have pointed out, the processes of individualisation that have affected adult family members have implications for children, who must also re-negotiate their family practices in terms of both the contributions they make to housework and, indeed, to carework (for empirical evidence, see Solberg 1997; Becker et al. 1998; Olsen 2000) and how they fit their schedules to those of their parents. They may also often spend less time with their (working) parents.

In addition, more also tends to be expected of children at school. Governments have focused increasingly on the welfare of children, but their orientation in most western countries has been on the child as a future 'worker citizen'. Thus in the UK the announcement of more investment in childcare in 2004 was justified in terms of the national interest: helping parents to reconcile work and family life, and helping children to get a good start in life because they are 'the citizens, workers, parents and leaders of the future' (HM Treasury 2004, paras 2.8, 2.11). The publication of international league tables on children's performance in school (for example OECD 2001) has resulted more generally in the promotion of early learning, standardising curricula and more educational testing.

This may be represented as an extension of the traditional concern to meet the needs of children. Certainly, the well-established developmental view of children, which clearly demarcated the boundary between child and 
adulthood, has served to recognise children's needs, mainly in terms of health and education (Thomas 2005). But historically children have been 'acted upon'. Indeed, comparisons of the treatment of children can be made with that of women in the nineteenth century, who were considered by lawmakers to be 'childlike' in terms of their lack of competence and autonomy (Lewis 1984; Land 2003; Näsman 1994). The boundary drawn by developmental psychologists between child and adulthood in terms of 'natural growth and development', has in fact much to do with economic dependence and power relations (Gittins 1998). Nevertheless, children are increasingly expected to take more responsibility for themselves and their development. In addition, the boundary seems in any case to be increasingly unclear. Postman (1994) has - controversially - argued that childhood is disappearing beneath the weight of consumerism and a mediadominated culture. Less spectacularly, it is possible to point out the extent to which education, historically the prerogative of the child, is now conceptualised as 'life-long', or the way in which sexual maturity is reached earlier and earlier, while economic dependency is prolonged. In Southern European countries in particular, young adults are continuing to live at home with their parents throughout their twenties.

Children are being affected by family and welfare state change, which raises the question of how to make policy more genuinely focused on children, especially when government policy tends to take an instrumentalist approach towards children's 'becoming' rather than being. The view of more recent academic work, particularly on the sociology of childhood, and of many of those working in supra-national organisations to prioritise the welfare of children, has been that the way forward lies in recognising the importance of the agency of the child in shaping childhood, rather than assuming the overwhelming importance of structures, particularly the institutions of the family and the school (see Prout and James 1997 for a review). Thus, for example, as Brannen and O'Brien (1996) put it, the focus should be on 'children in families' rather than on 'families with children'. Seeing children as agents with rights to participate in decisions affecting them raises a question mark over the more traditional developmental approach to childhood, which has tended to result in children being excluded from having a voice in the way they are treated by parents and lawmakers. Recent research, for example with children on their welfare in postdivorce families (Smart et al. 2001), has revealed the extent to which they cannot be considered immature, irrational and incompetent social actors, in contra-distinction to mature, rational and competent adults.

However, the logical end of solutions stressing agency and extending children's right to participation has limits that are not always acknowledged by some proponents (James and James 2004). If children's agency is 
over-emphasised to the exclusion of the need for protection, it is difficult to avoid making them at least in part responsible for securing their own welfare. As Minnow (1986) pointed out, confusion has arisen as a result of both advocates of greater protection for children - in the form of welfare rights - and the more extreme 'child liberationist' school, which would treat children as autonomous and equivalent to adults (for example Holt 1974) using the language of 'rights'. Any simple emphasis on rights threatens to play down the obligations that more powerful and better endowed adults have towards individual children and children as a group. After all, recent research on children's perspectives has shown the extent to which poverty limits children's capacity to make choices (Ridge 2002). Jones (2005) commented on the extent to which children in the UK feel more 'individualised' than do German children in terms of feeling more responsible for their success or failure, but are less able to capitalise on their choices because of structural disadvantage. Qvortrup (1995) argued strongly that children's lack of command over resources is unfair, given that their work at school, which is in the interests of society rather than the family, goes unrewarded until they reach adulthood. Adults 'choose' to have children, but children do not choose to be poor (see also Wintersberger 1994). The problem remains as to who is to speak for the child when it comes to resource allocation (O'Neill 1994), how far the child should also have a voice, and whether in any case this would be sufficient to guarantee his or her welfare.

What these academic debates and findings usefully do is alert us to the importance of the child's perspective in relation to social policymaking. Children have never been recognised as full citizens. T.H. Marshall (1950) gave them only limited rights, as 'citizens in the making'. If childhood and adulthood are firmly demarcated, then children will in all likelihood be 'acted-upon'. Family law has insisted that this be in their 'best interests', but, again, there remains a problem as to who will determine what these are. It is a major challenge to find the best way of conceptualising and representing children's interests. But the need to do so has become more pressing with rapid family and welfare state change. Much debate has focused on ways to move away from the traditional approach of simply protecting children, towards giving more recognition to some form of 'children's citizenship', and in particular to ways of allowing children to 'participate' and to have a say in their treatment (for example Stasiulis 2002). Ben-Arieh and Boyer (2005) have argued that children's participation is necessary if they are to be guaranteed their welfare entitlements. The most important formal document in this respect has been the 1989 UN Convention on the Rights of the Child, but there has also been more radical discussion, for example about the possibilities of extending the vote to children (for example, Ringen 1997; van Parijs 1999; see also Cutler and Frost 2001 who 
recommend lowering the voting age to 16 in the UK). However, some of these proposals are not necessarily child-centred, for example van Parijs's (1999) main preoccupation is to do something about the threat of gerontocracy in the face of population ageing.

To claim full citizenship for children of all ages is difficult. The UN Convention puts considerable emphasis on what might be considered the traditional 'welfare rights' of the child (to health and education), but also recognises the right of the child to 'voice' (Daniel and Ivatts 1998; James and Richards 1999). Neale (2002, p. 470) has advocated a 'social model of citizenship' that 'grounds the individualised rights of recognition, respect and participation within the relational ethics of care, responsibility and interdependence'. This also seeks to combine the more traditional concern about children's 'welfare rights' ${ }^{7}$ with the new recognition of the importance of participation. Some form of partial citizenship (Roche 1999) or 'citizenship in context' (Smart et al. 2001), offering a flexible model of citizenship for children with different kinds of participation at different levels, which endeavours to incorporate the idea of children as agents without losing sight of the fact that they are often in need of protection, has become more evident in the recent literature. This is similar to Stasiulis's (2002) vision of children's citizenship as protection and participation. The UNICEF Innocenti Research Centre has gone one step further by making an explicit effort to link the UN Convention's stress on the importance of participation on the part of children (Article 12), with its statement (in Article 5) that those with responsibility for children must take into account the 'evolving capacities' of the child to do so, by suggesting ways of promoting and measuring 'evolving capacity' (Lansdown 2005).

Children's views do provide an interesting and important commentary on family change and have implications for policy debates. For example, recent research with children has shown the extent to which they value 'ordinary time', and how longer parental working hours are perceived to reduce this (Christensen 2002; see also Brannen et al. 2000; Klammer, Chapter 11 this volume). It may also be that not all children need or want to keep in contact with both parents after divorce (Smart 2002, also James and James 1999). Hearing the voice of the child makes it harder to generalise on what is in the best interests of (all) children.

However, rights-based, citizenship models necessarily focus on the individual child and his or her need and capacity for protection and participation. One of the main messages of the chapters in this book is that policies affecting children as a group need to be child-centred if children are to thrive. This is not necessarily to make an argument that children can or should be treated as an undifferentiated group, but rather to draw additional attention to the policy drivers. As Minnow (1986) remarked two 
decades ago, children are all too often not the real focus of legislation directed towards them, which is often guided by other adult social interests and goals. The contributors to this volume focus on the two dimensions of financial support of and care for children. Efforts on the part of governments to tackle child poverty would appear to be unambiguously beneficial for children. But those efforts have included promoting female labour market participation, and there has been considerable debate about the consequences of this and of doing relatively little to promote the greater involvement of fathers in unpaid carework (see Hobson et al., Chapter 13 this volume) for children. Nevertheless, it is possible to argue that if parental time becomes more rare in the lives of children, the concept of 'quality time' can make up the difference. In the UK, where men's working hours are the longest in the EU, government has insisted that flexibility rather than the absolute number of working hours is key to securing children's well-being. However, not only do the views of children about family time (cited above) bring these positions into question, but it is also necessary to consider the extent to which the shift to an adult worker citizen model for adults has taken priority over consideration of what is best for children. A similar point can be made using the example of childcare provision. If the increase in formal childcare places is driven mainly by the fact that more mothers are in the labour market, then the priority is likely to be maximising the number of childcare places available. A more child-centred childcare policy will push the issue of quality, rather than quantity, up the policy agenda. As Lister (2005) has argued, it is necessary to look 'at children's well-being and citizenship together'; it is this that constitutes a childcentred approach to policymaking. Many of the contributions in this book look at the outcomes for children; where policy has been more childcentred, the outcomes are generally better.

The reorientation of welfare systems towards making a more 'active' link between the individual and the labour market, together with the new challenge being posed by population ageing, has resulted in more attention being paid to children. In large measure, this has resulted in a 'futurist' approach to children, which has to a great extent always characterised social policy. Children are protected, educated and valued for what they will become: future citizens. This 'social investment' approach, which has characterised the recent approach to social expenditure more generally, is explored by Jenson (Chapter 2) and Lister (Chapter 3) in Part I of the book. The approach has brought substantial benefits to children; the idea that future citizens cannot develop well in poverty has driven measures to reduce child poverty rates in those EU member states where the record was poorest, as Part II shows. Bradshaw (Chapter 4) provides an update of the amount of cash available for children in the tax and social security systems in 
15 countries, while both Björnberg (Chapter 5) and Bennett (Chapter 6) review the cross-national policy trends. While these are far from simple or convergent, many policy issues are common to a number of member states; for example, how far cash transfers in respect of children are made to depend on parents' performance as workers or as parents, and what kind of claim fathers, as opposed to mothers, are able to make on behalf of children.

The focus on the duty of adults to be in the labour market has made the issue of childcare more pressing. Part III of the book focuses on the care of children, with Pfau-Effinger (Chapter 7) showing both the extent to which the boundaries between formal and informal carework have become blurred, and the way in which parents have made a double claim to time to care on the one hand, and to childcare services on the other. Moss (Chapter 8) takes up the issue of childcare services and examines the limited meaning that is all too often given by providers to the idea of childcare, while Mahon (Chapter 9) explores the very different views of childcare that can be found in two recent and influential OECD reports on the subject. Finally, Part IV explores the tension between longer and/or more flexible hours in the labour market, which may lift more children out of poverty, but may also deprive children of ordinary family time. Letablier (Chapter 10) examines the complex interplay between greater flexibility at work, legislation limiting working hours, and the highly developed childcare system in France. Klammer (Chapter 11) and Perrons (Chapter 12) focus more on the problems and possibilities of flexibility in Germany and the UK, while Hobson et al. (Chapter 13) address the issue of fathers' working hours in particular, and the issues they raise for both children's welfare and mothers' choices about how to combine paid and unpaid work.

As Part IV shows, negotiating the shift to the adult worker model family is difficult, the interests of mothers, fathers and children at the household level may not be the same, and there may also be conflict between mothers, fathers, children and the state. Social policies may often prove to be rather a blunt instrument, but it is nevertheless possible to promote the same policy, for example, early years learning, with a more or less child-centred focus, and this matters for the welfare of children. Focusing on 'being' rather than 'becoming' requires a more child-centred approach.

\section{NOTES}

1. I am grateful to Ruth Lister for helping me think about the issues raised in this introduction. I have profited particularly from her recent writings on the subject (Lister 2005).

2. There is evidence to suggest that there is a gap between ideal and actual family size in Western European states (European Foundation for the Improvement of Living and Working Conditions 2005). 
3. We would also wish to acknowledge the wide range of policy issues that are crucial to children's welfare beyond financial support and care. The role of new media and the increased danger of public spaces in increasing the isolation of children are key.

4. The classic statement is that of Charles Murray (1984), but see also the idea of a 'parenting deficit' developed in the literature on social capital and community (Coleman 1988; Etzioni 1994).

5. The participation rates of mothers with dependent children increased by 10 per cent in West Germany, albeit that 52 per cent of them worked for fewer than 20 hours, a picture not so dissimilar from that in the UK.

6. These are pressing issues, but Pryor and Rodgers (2001) have shown the difficulties in assessing their effects.

7. Well-being may be a more appropriate term (Lister 2005; Dean 2006). See Bradshaw (2005) for a range of indicators to measure material well-being.

\section{REFERENCES}

Beck-Gernsheim, E. (1999), 'On the way to a post familial family: from a community of need to elective affinities', Theory, Culture and Society, 15(34), 53-70.

Beck-Gernsheim, E. (2002), Reinventing the Family: In Search of New Lifestyles, Cambridge: Polity Press.

Beck, U. and E. Beck-Gernsheim (1995), The Normal Chaos of Love, Oxford: Polity Press.

Becker, S., J. Aldridge and C. Dearden (1998), Young Carers and their Families, Oxford: Blackwell.

Ben-Arieh, A. and Y. Boyer (2005), 'Citizenship and childhood', Childhood, 12(1), 33-53.

Bonoli, G. (2005), 'The politics of the new social policies: providing coverage against new social risks in mature welfare states', Policy and Politics, 33(3), 431-49.

Borchorst, A. (2000), 'Danish childcare policy: continuity or restructuring', paper given to the GEP Conference, Vilvorde KursusCenter, Denmark, 18-20 August.

Bradshaw, J. (2000), 'Child poverty in comparative perspective', in D. Gordon and P. Townsend (eds), Breadline Europe, Bristol: Policy Press.

Bradshaw, J. (2005), The Well-being of Children in the UK, London: Save the Children.

Brannen, J., E. Heptinstall and K. Bhopal (2000), Connecting Children. Care and Family Life in Later Childhood, London: Routledge Falmer.

Brannen, J. and M. O'Brien (eds) (1996), Children in Families: Research and Policy, Brighton: Falmer Press.

Brush, L.D. (2002), 'Changing the subject: gender and welfare regime studies', Social Politics, 9(2), 161-86.

Christensen, P.H. (2002), "Why more "quality time" is not on the top of children's lists: the "qualities of time" for children', Children and Society, 16, 77-88.

Coleman, J.S. (1988), 'Social capital in the creation of human capital', American Journal of Sociology, 94(supplement), S95-S120.

Commission of the European Communities (CEC) (2000), Towards a Community Framework Strategy on Gender Equality (2001-2005), COM (2000) 335 final, 7 June, Brussels.

Commission of the European Communities (CEC) (2002), Increasing Labour Force Participation and Promoting Active Ageing, COM (2002) 9 final, Brussels. 
Commission of the European Communities (CEC) (2005), 'Confronting Demographic Change: A New Solidarity between the Generations', green paper COM (2005) 94 final, Brussels, 16 March.

Council of the European Union (2000), 'Conclusions of the Presidency', Lisbon European Council of 23-24 March.

Council of the European Union (2001), 'Conclusions of the Presidency', Stockholm European Council of 23-24 March.

Crompton, R. (ed.) (1999), Restructuring Gender Relations and Employment: The Decline of the Male Breadwinner, Oxford: Oxford University Press.

Crouch, C. (1999), Social Change in Western Europe, Oxford: Oxford University Press.

Cutler, D. and R. Frost (2001), Taking the Initiative: Promoting Young People's Involvement in Public Decision-making in the UK, London: Carnegie UK Trust.

Dahlberg, G., P. Moss and A. Pence (1999), Beyond Quality in Early Childhood Education and Care: Postmodern Perspectives, London: Routledge.

Daniel, P. and J. Ivatts (1998), Children and Social Policy, Basingstoke: Macmillan.

Dean, H. (2006), Social Policy, Cambridge: Polity Press.

Dingeldey, I. (2001), 'European tax systems and their impact on family employment patterns', Journal of Social Policy, 30(4), 653-72.

Douglass, C.B. (ed.) (2005), Barren States. The Population 'Implosion' in Europe, Oxford: Berg.

Duncan, S. and R. Edwards (1999), Lone Mothers, Paid Work and Gendered Moral Rationalities, Basingstoke: Macmillan.

Elias, N. (1991), The Society of Individuals, Oxford: Blackwell.

Elshtain, J.-B. (1990), 'The family and civil life', in D. Blankenhorn, S. Bayme and J.-B. Elshtain (eds), Rebuilding the Nest: A New Commitment to the American Family, Milwaukee; WI: Family Service America.

Esping-Andersen, G. (1999), Social Foundations of Post-industrial Economies, Oxford: Oxford University Press.

Esping-Andersen, G. (2001), 'A new welfare architecture for Europe?', final version of a report submitted to the Belgian Presidency of the European Union.

Esping-Andersen, G., D. Gallie, A. Hemerijcke and J. Myles (2002), Why We Need a New Welfare State, Oxford: Oxford University Press.

Etzioni, A. (1994), The Spirit of Community: The Reinvention of American Society, New York: Touchstone Books.

European Foundation for the Improvement of Living and Working Conditions (2000), Employment and Working Time in Europe, Dublin: European Foundation.

European Foundation for the Improvement of Living and Working Conditions (2005), Fertility and Family Issues in an Enlarged Europe, Dublin: European Foundation.

Evers, A., J. Lewis and B. Reidel (forthcoming 2006), 'Developing Childcare Provision in England and Germany: Dilemmas of Governance', Journal of European Social Policy, 15(3).

Ferrera, M., A. Hemerijck and M. Rhodes (2000), The future of social Europe recasting work and welfare in the New Economy, report for the Portuguese Presidency of the European Union.

Gershuny, J. (2000), Changing Times, Oxford: Oxford University Press.

Gillis, J. (2003), 'Childhood and family time: a changing historical relationship', in A.-M. Jensen and L. McKee (eds), Children and the Changing Family: Between Transformation and Negotiation, London: Routledge Falmer. 
Gittins, D. (1998), The Child in Question, Basingstoke: Macmillan.

Gordon, L. (ed.) (1988), Heroes of Their Own Lives: The Politics and History of Family Violence, Boston 1880-1960, New York: Viking.

Gregg, P. and E. Washbrook (2003), 'The effects of early maternal employment on child development in the UK', CMPO working paper.

Hendrick, H. (1990), 'Constructions and reconstructions of British childhood: an interpretative survey, 1800 to the present', in A. James and A. Prout (eds), Constructing and Reconstructing Childhood: Contemporary Issues in the Sociological Study of Childhood, London: Routledge.

Heymann, J. (2000), The Widening Gap. Why America's Working Families are in Jeopardy and What Can be Done about it, New York: Basic Books.

H.M. Treasury (2004), Choice for Parents, the Best Start for Children: A Ten Year Strategy for Childcare, London: H.M. Treasury.

Holt, J. (1974), Escape from Childhood: The Needs and Rights of Children, Harmondsworth: Penguin.

Huber, E. and J. Stephens (2001), Development and Crisis of the Welfare State. Parties and Policies in Global Markets, Chicago: University of Chicago Press.

James, A.L. and A. James (1999), 'Pump up the volume: listening to children in separation and divorce', Childhood, 6(2), 189-206.

James, A.L. and A. James (2001), 'Tightening the net: children, community and control,' British Journal of Sociology, 52(2), 211-28.

James, A. and A.L. James (2004), Constructing Childhood. Theory, Policy and Social Practice, Basingstoke: Macmillan.

James, A.L. and M.P.M. Richards (1999), 'Sociological perspectives, family policy, family law and children: adult thinking and sociological tinkering', The Journal of Social Welfare and Family Law, 21(1), 23-40.

Jensen, A.-M. (2003), 'For the children's sake. Symbolic power lost?', in A.-M. Jensen and L. McKee (eds), Children and the Changing Family: Between Transformation and Negotiation, London: Routledge Falmer.

Jensen, A.-M. and L. McKee (2003), 'Introduction: theorizing childhood and family change', in A.-M. Jensen and L. McKee (eds), Children and the Changing Family: Between Transformation and Negotiation, London: Routledge Falmer.

Jones, G. (2005), Young Adults and the Extension of Economic Dependence, London: National Family and Parenting Institute.

Kiernan, K., H. Land and J. Lewis (1998), Lone Motherhood in Twentieth-century Britain, Oxford: Oxford University Press.

Korpi, W. (2000), 'Faces of inequality: gender, class, and patterns of inequalities in different types of welfare states', Social Politics, 7(2), 127-91.

Land, H. (2003), 'Children, families, states, and changing citizenship', in J. Scot, J. Treas and M.P.M. Richards (eds), The Blackwell Companion to the Sociology of Families, Oxford: Blackwell.

Lansdown, G. (2005), The Evolving Capacities of the Child, Florence: UNICEF Innocenti Research Centre and Save the Children.

Lewis, J. (1984), Women in England, 1870-1950, Brighton: Harvester/Wheatsheaf.

Lewis, J. (1992), 'Gender and the development of welfare regimes', Journal of European Social Policy, 3, 159-73.

Lewis, J. (ed.) (1997), Lone Mothers in European Welfare Regimes, London: Jessica Kingsley.

Lewis, J. (2001), 'The decline of the male breadwinner model: the implications for work and care', Social Politics, 8(2), 152-70. 
Lewis, J. (2002), 'Gender and welfare state change', European Societies, 4(4), 331-57.

Lewis, J. (2003a), Should We Worry About Family Change?, Toronto: University of Toronto Press.

Lewis, J. (2003b), 'Developing Early Years Childcare in England, 1997-2002: The Choices for (Working) Mothers', Social Policy and Administration, 37(3), 219-38.

Lister, R. (2005), 'Children, well-being and citizenship', paper presented to the Social Policy Association Annual Conference, University of Bath, 27-29 June.

Livingstone, S. (2002), Young People and New Media, London: Sage.

Lynott, P.P. and B.J. Logue (1993), 'The "Hurried Child": The Myth of Lost Childhood in Contemporary American Society', Sociological Forum, 8(3), 471-89.

Manning, A. and B. Petrongolo (2005), The Part-time Pay Penalty, London: DTI.

Marshall, T.H. (1950), Citizenship and Class and other Essays, Cambridge: Cambridge University Press.

Miller, P. (2005), 'Useful and priceless children in contemporary welfare states', Social Politics, 12(1), 3-41.

Minnow, M. (1986), 'Rights for the next generation: a feminist approach to children's rights', Harvard Women's Law Journal, 9(1), 1-24.

Mount, F. (1983), The Subversive Family: An Alternative History of Love and Marriage, London: Allen and Unwin.

Murray, C. (1984), Losing Ground: American Social Policy 1950-1980, New York: Basic Books.

Mutari, E. and D. Figart (2001), 'Europe at a crossroads: harmonization, liberalization, and the gender of work time', Social Politics, 8, 36-64.

Näsman, E. (1994), 'Individualization and institutionalization of childhood in today's Europe', in J. Qvortrup, M. Bardy, G. Sigritta and H. Wintersberger (eds), Childhood Matters. Social Theory, Practice and Politics, Aldershot: Avebury.

Neale, B. (2002), 'Dialogues with children. Children, divorce and citizenship', Childhood, 9(4), 455-75.

Organisation for Economic Co-operation and Development (OECD) (2001), Knowledge and Skills for Life: First Results from PISA 2000, Paris: OECD.

Olsen, R. (2000), 'Families under the microscope: parallels between the young carers debate of the 1990s and the transformation of childhood in the late nineteenth century', Children and Society, 14, 384-94.

O'Neill, J. (1994), The Missing Child in Liberal Theory, Toronto: University of Toronto Press.

Orloff, A. (1993), 'Gender and the social rights of citizenship. State policies and gender relations in comparative research', American Sociological Review, 58(3), 303-28.

Parijs, P. van (1999), 'The disfranchisement of the elderly, and other attempts to secure intergenerational justice', Philosophy and Public Affairs, 27, 292-333.

Pierson, P. (ed.) (2001), The New Politics of the Welfare State, Oxford: Oxford University Press.

Postman, M. (1994), The Disappearance of Childhood, New York: Vintage Books.

Prout, A. and A. James (1997), 'A new paradigm for the sociology of childhood? Provenance, promise and problems', in A. James and A. Prout (eds), Constructing and Reconstructing Childhood. Contemporary Issues in the Sociological Study of Childhood, London: Routledge Falmer.

Pryor, J. and B. Rodgers (2001), Children in Changing Families. Life after Parental Separation. Oxford: Blackwell.

Qvortrup, J. (1995), 'From useful to useful: the historical continuity of children's constructive participation', Sociological Studies of Children, 7, 49-76. 
Rathbone, E. (1924), The Disinherited Family, London: Edward Arnold.

Ridge, T. (2002), Childhood Poverty and Social Exclusion: From a Child's Perspective, Bristol: Policy Press.

Ringen, S. (1997), Citizens, Families, and Reform, Oxford: Clarendon Press.

Ritakallio, V.-M. and Bradshaw (2006), 'Family poverty in the European Union', in J. Bradshaw and A. Hatland (eds), Social Policy, Employment and Family Change in Comparative Perspective, Cheltenham; UK and Northampton, MA, USA: Edward Elgar (in press).

Roche, J. (1999), 'Children: rights, participation and citizenship', Childhood, 6(4), 475-93.

Rowlingson, K. and J. Millar (eds) (2001), Lone Parents, Employment and Social Policy: Cross-national Comparisons, Bristol: Policy Press.

Rubery, J. (2002), 'Gender mainstreaming and gender equality in the EU employment strategy', Industrial Relations Journal, 33(5), 30-56.

Rubery, J., M. Smith and C. Fagan (1999), Women's Employment in Europe, London: Routledge.

Schor, J. (2001), The Overworked American, New York: Basic Books.

Sharma, V. (2005), Women's and Children's Poverty: Making the Links, London: Women's Budget Group.

Skocpol, T. (2000), The Missing Middle: Working Families and the Future of American Social Policy, New York: W.W. Norton \& Company.

Smart, C. (2002), 'From children's shoes to children's voices', paper presented to the seminar on 'The Children of Divorce: Parentage and Citizenship', Institute d'Infancia i Món Urbà, Barcelona, 19-20 September.

Smart, C., B. Neale and A. Wade (2001), The Changing Experience of Childhood, Families and Divorce, Oxford: Polity Press.

Smith, A. (2004), 'Who cares? Fathers and the time they spend looking after children', paper presented to the International Conference on Work and Family, CRFR, University of Edinburgh, 30 June-2 July.

Solberg, A. (1997), 'Negotiating childhood: changing constructions of age for Norwegian children', in A. James and A. Prout (eds), Constructing and Reconstructing Childhood: Contemporary Issues in the Sociological Study of Childhood, London: Falmer Press.

Stasiulis, D. (2002), 'The active child citizen: lessons from Canadian policy and the children's movement', Citizenship Studies, 6(4), 507-36.

Stratigaki, M. (2004), 'The co-optation of gender concepts in EU policies: the case of "reconciliation of work and family", Social Politics, 11(1), $30-56$.

Stratigaki, M. (2005), 'Gender mainstreaming vs positive action. An ongoing conflict in EU gender equality policy', European Journal of Women's Studies, 12(2), 165-86.

Thomas, N. (2005), 'Interpreting children's needs: contested assumptions in the provision of welfare', in J. Goddard, S. McNamee, A. James and Allison James (eds), The Politics of Childhood. International Perspectives, Contemporary Developments, Basingstoke: Palgrave Macmillan.

Vandenbroucke, F. (2001), 'European social democracy and the third way: convergence, divisions, and shared questions', in S. White (ed.), New Labour: The Progressive Future?, Basingstoke: Palgrave.

Vleminckx, V. and T.M. Smeeding (eds) (2001), Child Well-being, Child Poverty and Child Policy in Modern Nations, Bristol: Policy Press. 
Wintersberger, H. (1994), 'Costs and benefits - the economics of childhood', in J. Qvortrup, M. Bardy, G. Sigritta and H. Wintersberger (eds), Childhood Matters. Social Theory, Practice and Politics, Aldershot: Avebury.

Yeandle, S. (1999), 'Gender contracts, welfare systems and non-standard working: diversity and change in Denmark, France, Germany, Italy and the UK', in A. Felstead and N. Jewson (eds), Global Trends in Flexible Labour, Basingstoke: Macmillan.

Zselizer, V. (1985), Pricing the Priceless Child: The Changing Social Value of Children, New York: Basic Books. 